\title{
Growth, Visual Quality, and Morphological Responses of 12 Viburnum Taxa to Saline Water Irrigation
}

\author{
Youping Sun and Ji Jhong Chen \\ Department of Plants, Soils, and Climate, Utah State University, 4820 Old \\ Main Hill, Logan, UT 84322
}

\section{Haifeng Xing}

College of Grassland Resources and Environment, Inner Mongolia Agricultural University, Hohhot, Inner Mongolia 010010, China

\section{Asmita Paudel}

Department of Plants, Soils, and Climate, Utah State University, 4820 Old Main Hill, Logan, UT 84322

\section{Genhua Niu \\ Department of Horticultural Sciences, Texas A\&M AgriLife Research Center at Dallas, Texas A\&M University, 17360 Coit Road, Dallas, TX 75252}

\section{Matthew Chappell \\ Department of Horticulture, University of Georgia, 326 Hoke Smith Building, Athens, GA 30602}

Additional index words. chlorophyll content, landscape plant, salinity, salinity tolerance, Viburnum, visual quality

\begin{abstract}
Viburnums are widely used in gardens and landscapes throughout the United States. Although salinity tolerance varies among plant species, research-based information is limited on the relative salt tolerance of viburnum species. The morphological and growth responses of 12 viburnum taxa to saline solution irrigation were evaluated under greenhouse conditions. Viburnum taxa included Viburnum $\times$ burkwoodii, $V$. cassinoides 'SMNVCDD', $V$. dentatum 'Christom', $V$. dentatum var. deamii 'SMVDLS', $V$. dilatatum 'Henneke', V. ×'NCVX1', V. nudum 'Bulk', V. opulus 'Roseum', V. plicatum var. tomentosum 'Summer Snowflake', $V$. pragense 'Decker', $V$. X rhytidophylloides 'Redell', and $V$. trilobum. A nutrient solution at an electrical conductivity (EC) of $1.3 \mathrm{dS} \cdot \mathrm{m}^{-1}$ (control) or saline solutions at ECs of 5.0 and $10.0 \mathrm{dS} \cdot \mathrm{m}^{-1}$ were applied eight times over a 9-week period. Growth, visual quality, and morphological characteristics were quantified at the 4th week and 8th-9th week to assess the impact of salinity stress on the viburnum taxa. Saline solution irrigation imposed detrimental salinity stress on viburnum plant growth and visual quality, and the degree of salt damage was dependent on the salinity levels of irrigation solution and the length of exposure to salinity stress as well as viburnum taxa. Viburnum $\times$ burkwoodii and $V . \times$ 'NCVX1' had little foliar salt damage during the entire experiment, except those irrigated with saline solution at an EC of $10.0 \mathrm{dS} \cdot \mathrm{m}^{-1}$ exhibited slight to moderate foliar salt damage at the eighth week. Viburnum dilatatum 'Henneke', $V$. plicatum var. tomentosum 'Summer Snowflake', and $V$. trilobum irrigated with saline solution at an EC of $5.0 \mathrm{dS} \cdot \mathrm{m}^{-1}$ had slight and severe foliar salt damage at the 4th and 8th week, respectively. Plants irrigated with saline solution at an EC of $10.0 \mathrm{dS} \cdot \mathrm{m}^{-1}$ exhibited severe foliar salt damage at the 4th week, and all died by the 8th week. Other viburnum taxa also showed various foliar salt damage, especially at an EC of $10.0 \mathrm{dS} \cdot \mathrm{m}^{-1}$. The shoot dry weights of $V$. $\times$ burkwoodii and $V . \times$ 'NCVX1' irrigated with saline solution at ECs of 5.0 and 10.0 $\mathrm{dS} \cdot \mathrm{m}^{-1}$ were similar to those in the control at both harvest dates. However, the shoot dry weight of other tested viburnum taxa decreased to some extent at the 9th week. A cluster analysis concluded that $V . \times$ burkwoodii and $V . \times$ 'NCVX1' were considered the most salttolerant viburnum taxa, whereas $V$. dilatatum 'Henneke', $V$. plicatum var. tomentosum 'Summer Snowflake', and $V$. trilobum were sensitive to salinity levels used in this study. This research may guide the green industry to choose relatively tolerant viburnum taxa for landscape use and nursery production where low-quality water is used for irrigation.
\end{abstract}

Salinity is one of the most significant environmental challenges when growing ornamental plants throughout the world. In arid and semiarid regions, low-quality water, such as treated and reclaimed municipal effluent (reclaimed water) and industrial wastewater, is often used for landscape irrigation to save potable water and overcome water shortages (Yeager et al., 2010). Reclaimed water may contain excessive sodium chloride $(\mathrm{NaCl})$ that affects plant growth and development aesthetically and morphologically (Álvarez and Sánchez-Blanco, 2014). Reclaimed water irrigation can induce foliar damage on landscape plants resulting in poor overall landscape appearance. As more communities are considering reclaimed water irrigation, it is urgent to identify salt-tolerant plants for landscape use.

Significant differences in salinity tolerance exist among plant species and cultivars Most plants cannot thrive when $\mathrm{NaCl}$ concentration reaches 100 to $200 \mathrm{~mm}$, but halophytes can survive in 300 to $500 \mathrm{~mm} \mathrm{NaCl}$ solution (Munns and Tester, 2008). Morphological symptoms resulting from salinity stress include stunted growth and foliar damage (leaf burn, necrosis). For example, Cassaniti et al. (2009) observed that Bougainvillea glabra (paperflower), Cestrum fasciculatum (early jessamine), Eugenia myrtifolia (syn. Syzygium paniculatum) (brush cherry), Leptospermum scoparium (manuka), Leucophyllum frutescens (Texas sage), Ruttya fruticosa (jammy mouth), and Viburnum lucidum (arrow wood) irrigated with $70 \mathrm{~mm}$ $\mathrm{NaCl}$ solution had a $3 \%$ to $25 \%$ reduction in relative growth rate (RGR) compared with those irrigated with a $10 \mathrm{~mm} \mathrm{NaCl}$ solution. In extreme cases, such as Cotoneaster lacteus (milkflower cotoneaster), a reduction of $75 \%$ in RGR is possible. Cassaniti et al. (2009) found that Grevillea juniperina (juniper-leaf grevillea) had $21 \%$ damaged leaves when they were irrigated with $40 \mathrm{~mm} \mathrm{NaCl}$ solution, and all leaves were damaged at $70 \mathrm{~mm}$ $\mathrm{NaCl}$. Leaf necrosis of $C$. lacteus reached $62 \%$ from 10 to $40 \mathrm{~mm} \mathrm{NaCl}$ and up to $79 \%$ at $70 \mathrm{~mm} \mathrm{NaCl}$, but $V$. lucidum had no saltinduced symptoms at either concentration.

Salinity stress can also result in a reduction in leaf size and defoliation. Viburnum lucidum had 54\% and 48\% less leaf number and leaf area, respectively, when irrigated with $200 \mathrm{~mm} \mathrm{NaCl}$ solution compared with the control (0 $\mathrm{mm} \mathrm{NaCl})$ (Cirillo et al., 2016). Bañón et al. (2012a, 2012b) found that 24\% of leaves abscised and leaf area decreased by $48 \%$ when $V$. tinus (laurustinus viburnum) was irrigated with saline solution at an EC of $6.0 \mathrm{dS} \cdot \mathrm{m}^{-1}$ compared with the control $(2.0$ $\mathrm{dS} \cdot \mathrm{m}^{-1}$ ). Callistemon citrinus (red bottlebrush) had a reduction in leaf area of $12 \%$ when irrigated with $44 \mathrm{~mm} \mathrm{NaCl}$ solution $\left(4.0 \mathrm{dS} \cdot \mathrm{m}^{-1}\right)$ compared with the control $\left(0.8 \mathrm{dS} \cdot \mathrm{m}^{-1}\right)$ (Álvarez and Sánchez-Blanco, 2014).

Reduction in biomass production has been observed in many ornamental plants under high-salinity conditions. Carthamus tinctorius (safflower) irrigated with a Hewitt (1966) nutrient solution containing $60 \mathrm{~mm}$ potassium chloride $(\mathrm{KCl})$ had a $15 \%$ reduction in whole plant dry weight compared with those irrigated with Hewitt's nutrient solution (Farhat et al., 2013). Shoot dry weight of Coleus blumei (coleus) treated with saline solution reduced when $\mathrm{NaCl}$ concentration increased 
from 0 to $60 \mathrm{~mm}$ (Ibrahim et al., 1990). Viburnum lucidum watered with $80 \mathrm{~mm} \mathrm{NaCl}$ or $53.3 \mathrm{~mm}$ calcium chloride $\left(\mathrm{CaCl}_{2}\right)$ had a $28 \%$ reduction in shoot dry weight, but there was no significant change in the root dry weight compared with no salt treatment (Cirillo et al., 2019). When the salinity level of irrigation water increased to $200 \mathrm{~mm} \mathrm{NaCl}$ $\left(20.5 \mathrm{dS} \cdot \mathrm{m}^{-1}\right)$, the shoot and root dry weight of $V$. lucidum dropped by $37 \%$ and $29 \%$, respectively, compared with the control (1.6 $\mathrm{dS} \cdot \mathrm{m}^{-1}$ ) (Cassaniti et al., 2009). Similarly, $C$. tinctorius plants suffered $61 \%, 50 \%$, and $55 \%$ reductions in leaf, stem, and root dry weights, respectively, when irrigated with $40 \mathrm{~mm} \mathrm{CaCl}_{2}$ compared with the control $\left(0.8 \mathrm{dS} \cdot \mathrm{m}^{-1}\right)$ (Rabhi et al., 2018). However, the total plant dry weight of $C$. citrinus did not decrease when irrigated with $44 \mathrm{~mm} \mathrm{NaCl}$ solution $\left(4 \mathrm{dS} \cdot \mathrm{m}^{-1}\right)$ compared with the control $\left(0.8 \mathrm{dS} \cdot \mathrm{m}^{-1}\right)$ (Álvarez and SánchezBlanco, 2014).

Plant shoot growth is more sensitive to salinity stress than root growth, and an increased root-to-shoot $(\mathrm{R} / \mathrm{S})$ ratio is expected in response to salinity stress (Hanin et al., 2016). Cirillo et al. (2019) determined that the $\mathrm{R} / \mathrm{S}$ ratio increased from 0.49 to 0.61 in $V$. lucidum and from 0.37 to 0.46 in C. citrinus when the EC of irrigation water increased from 2.0 to $11.0 \mathrm{dS} \cdot \mathrm{m}^{-1}$. Acosta-Motos et al. (2015) also observed an increasing $\mathrm{R} / \mathrm{S}$ ratio in Myrtus communis (common myrtle) plants irrigated with $\mathrm{NaCl}$ solution at an $\mathrm{EC}$ of 8.0 $\mathrm{dS} \cdot \mathrm{m}^{-1}$ for 1 month. However, Bañón et al.

Received for publication 18 Feb. 2020. Accepted for publication 23 Apr. 2020.

Published online 8 July 2020.

This research was supported in part by the U.S. Department of Agriculture (USDA) National Institute of Food and Agriculture Hatch Project UTA01381 and TEX090450 and USDA Specialty Crop Block Grant Program (no. 202715), New Faculty Start-Up Funds from the Office of Research and Graduate Studies, the Center for Water-Efficient Landscaping, and the Utah Agricultural Experiment Station (UAES) at Utah State University. This research was also supported in part by the Center for Applied Nursery Research, a nonprofit research center located in Dearing, GA. It is approved as UAES journal paper no. 9326. We appreciate the financial support from China Scholarship Council to Haifeng Xing as a visiting scholar at Utah State University, Logan, UT. We are grateful for the in-kind support of plant materials from Spring Meadow Nursery (Grand Haven, MI) and valuable comments from anonymous reviewers. The content is solely the responsibility of the authors and does not necessarily represent the official views of the funding agencies. Mention of a trademark, proprietary product, or vendor does not constitute a guarantee or warranty of the product by the USDA or the American Society for Horticultural Science and does not imply its approval to the exclusion of other products or vendors that also may be suitable.

Y.S. and H.X. are the corresponding authors. E-mail: youping.sun@usu.edu or nmgxinghaifeng@ 126.com

This is an open access article distributed under the CC BY-NC-ND license (https://creativecommons.org/ licenses/by-nc-nd/4.0/). (2012a, 2012b) indicated that the R/S ratio of $V$. tinus decreased from 0.34 to 0.29 when the EC of irrigated saline solutions increased from 2.0 to $6.0 \mathrm{dS} \cdot \mathrm{m}^{-1}$. These reports indicate that there is a species-dependent, if not cultivar-dependent, response to salinity on $\mathrm{R} / \mathrm{S}$ ratios.

Viburnums are popular garden and landscape plants in North America due to rich foliage, fragrant flowers, bright color, variability in plant size and habit, and abundant colorful fruit. For example, V. lucidum is a popular ornamental flowering shrub with high market demand across the United States (Cirillo et al., 2016; Lippi et al., 2003). Cassaniti et al. (2009) reported that V. lucidum can tolerate salinity levels up to 7.4 $\mathrm{dS} \cdot \mathrm{m}^{-1}$ in a 120 -day period showing less than $25 \%$ reduction in RGR. Laura (2009) reported that viburnum species, including $V$. lentago (nannyberry viburnum), V. prunifolium (blackhaw viburnum), V. opulus (European cranberrybush viburnum), $V$. trilobum (American cranberrybush viburnum), and $V$. dentatum (arrowwood viburnum), exhibited moderate tolerance to salt spray or soil salinity without giving a criterion. However, Beckerman and Lerner (2009) documented that viburnum species were sensitive to salt spray with no criterion. In contrast, Bañón et al. (2012a, 2012b) indicated that $V$. tinus was sensitive to saline solution irrigation at an EC of $6.0 \mathrm{dS} \cdot \mathrm{m}^{-1}$. Among 150 to 175 species of Viburnum, many species (and cultivars) are yet to be evaluated for salinity tolerance. Additional information on the salinity tolerance of viburnum species would be beneficial to determine optimal taxa for poor water quality environments. The present study was designed to compare the growth of 12 viburnum taxa in response to saline solution irrigation at different salinity levels.

\section{Materials and Methods}

Plant materials. A total of 12 viburnum taxa, donated by Spring Meadow Nursery (Grand Haven, MI), were used in this study (Table 1). On 7 Feb. 2019, rooted cuttings $(\approx 6 \mathrm{~cm}$ tall) were received. One week later, viburnum cuttings were transplanted into 3.8L injection-molded polypropylene containers (PC1D-4; Nursery Supplies, Orange, CA) containing soilless growing substrate. The substrate consisted of $75 \%$ peatmoss (Canadian sphagnum peatmoss; SunGro Horticulture, Agawam, MA), 25\% vermiculite (Therm-O-Rock West, Chandler, AZ), 0.86 $\mathrm{kg} \cdot \mathrm{m}^{-3}$ gypsum $(92 \%$ calcium sulfate dihydrate, $21 \%$ calcium, $17 \%$ sulfur; Western Mining and Minerals, Bakersfield, CA), 9 $\mathrm{kg} \cdot \mathrm{m}^{-3}$ dolomitic lime (Lhoist North America, Salinas, CA), and $0.59 \mathrm{~kg} \cdot \mathrm{m}^{-3}$ wetting agent (AquaGro 2000G; Aquatrols, Paulsboro, NJ). Plants were watered with tap water (Table 2; $\mathrm{EC}=0.37 \mathrm{dS} \cdot \mathrm{m}^{-1} ; \mathrm{pH}=8.19$ ) before the experiment. Bifenthrin (Talstar; FMC Corporation, Philadelphia, PA) at 7.8 $\mathrm{mL} / \mathrm{L}$ was foliar-applied to all plants as needed because spider mites (Oligonychus ilicis) were observed on $V$. dilatatum 'Hen- neke', V. opulus 'Roseum', and V. plicatum var. tomentosum 'Summer Snowflake'.

Treatments. On 26 Mar. 2019, uniform plants of each species/cultivar were selected and randomly assigned to three groups for the experiment. Within each group, 10 plants were used for all taxa except $V$. $\times{ }^{\prime} \mathrm{NCVX} 1$ ', of which six plants were received. Viburnum opulus 'Roseum' and V. trilobum were pruned to $20 \mathrm{~cm}$ tall to remove apical dominance. On 28 Mar. 2019, a nutrient solution at an EC of $1.3 \mathrm{dS} \cdot \mathrm{m}^{-1}$ (control) or two saline solutions at an EC of 5.0 or $10.0 \mathrm{dS} \cdot \mathrm{m}^{-1}$ (Table 2) were assigned to the three treatments (groups) within each species/cultivar. A water-soluble fertilizer $15 \mathrm{~N}-2.2 \mathrm{P}-12.5 \mathrm{~K}$ (Peters 15-5-15 Cal-Mag Special; Scotts, Marysville, $\mathrm{OH}$ ) at $0.8 \mathrm{~g} \cdot \mathrm{L}^{-1}$ was dissolved in tap water to create the nutrient solution at an average $\mathrm{EC}$ of $1.31 \pm 0.08 \mathrm{dS} \cdot \mathrm{m}^{-1}$ (mean \pm SD), which represented the control treatment. The same nutrient solution was spiked with $\mathrm{NaCl}$ (Fisher Scientific, Waltham, MA) at $0.92 \mathrm{~g} \cdot \mathrm{L}^{-1}$ and dihydrate calcium chloride $\left(\mathrm{CaCl}_{2} \cdot 2 \mathrm{H}_{2} \mathrm{O}\right.$; Hi Valley Chemical, Centerville, UT) at $1.17 \mathrm{~g} \cdot \mathrm{L}^{-1}$ to create the saline treatment at an EC of $5.07 \pm 0.04 \mathrm{dS} \cdot \mathrm{m}^{-1}$ (EC 5 ). The same base (control) solution was supplemented with $2.27 \mathrm{~g} \cdot \mathrm{L}^{-1} \mathrm{NaCl}$ and $2.88 \mathrm{~g} \cdot \mathrm{L}^{-1} \mathrm{CaCl}_{2} \cdot 2 \mathrm{H}_{2} \mathrm{O}$ to create the saline treatment at an EC of $10.08 \pm 0.04 \mathrm{dS} \cdot \mathrm{m}^{-1}$ (EC 10). The $\mathrm{pH}$ of all solutions was adjusted using $1 \mathrm{~mol} \cdot \mathrm{L}^{-1}$ nitric acid to $6.00 \pm 0.02$. Before irrigation, the treatment solutions were measured to confirm the EC levels using an EC meter (LAQUA Twin; Horiba, Kyoto, Japan). From 28 Mar. to 16 May 2019, plants were manually irrigated weekly, eight times in total, with the treatment assigned to each plant in the study. At each treatmentirrigation event, $1 \mathrm{~L}$ of treatment solution was applied, resulting in a leaching fraction of $33.2 \% \pm 2.3 \%$. Between weekly treatment events and after the eighth treatment, the control nutrient solution $(\approx 500 \mathrm{~mL})$ was applied to maintain substrate moisture. Five plants per treatment per taxon were randomly selected and destructively harvested on 27 Apr. 2019 (first harvest, 4 weeks after the initiation of treatment), the remaining five plants were harvested on 31 May 2019 (second harvest, 9 weeks after the initiation of treatment). Viburnum $\times$ 'NCVX1' was harvested at the second harvest only because all plants had no foliar salt damage.

Greenhouse condition. All viburnum plants were grown in a research greenhouse at Utah State University in Logan, UT (lat. $41^{\circ} 45^{\prime} 28^{\prime \prime} \mathrm{N}$, long. $111^{\circ} 48^{\prime} 47^{\prime \prime} \mathrm{W}$, elevation $1409 \mathrm{~m})$. From 28 Mar. to 14 May, the average air temperature in the greenhouse was $25.4 \pm 0.5^{\circ} \mathrm{C}$ during the day and $21.7 \pm$ $2.3{ }^{\circ} \mathrm{C}$ at night. The average daily light integral was $24.9 \pm 10.4 \mathrm{~mol} \cdot \mathrm{m}^{-2} \cdot \mathrm{d}^{-1}$ inside the greenhouse. Supplemental light at an averaged intensity of $160.4 \mu \mathrm{mol} \cdot \mathrm{m}^{-2} \cdot \mathrm{s}^{-1}$ at plant canopy level was provided using $1000-\mathrm{W}$ high-pressure sodium lamps (Hydrofarm, Petaluma, CA) from 0600 to $2200 \mathrm{HR}$ when light intensity inside the greenhouse was less than 544 $\mu \mathrm{mol} \cdot \mathrm{m}^{-2} \cdot \mathrm{s}^{-1}$ during the entire experiment. 
Data collection. A pour-through technique (Cavins et al., 2008) was used to determine the EC level of leachate solution of one randomly chosen plant per taxon per treatment after treatment solutions were applied weekly. When measurements were taken, EC values were averaged across 12 taxa each week. A saturated soil paste technique (Gavlak et al., 1994) with some modifications was used to determine the final substrate EC. After harvest, the containers with substrate were dried for 2 weeks in the greenhouse, and the substrate at the surface $(\approx 2-3 \mathrm{~cm})$ was sampled for soil extraction because a majority of salts moved up during the drying process. A total of $10 \mathrm{~g}$ substrate sample was added to $60 \mathrm{~mL}$ deionized water to make the paste, and the soil paste was stored overnight at room temperature before EC measurements were taken. Three containers per treatment per taxon were randomly selected and sampled for each harvest date.

Visual quality of each plant was recorded at both harvest dates using a five-point scale (visual score), where $0=$ dead; $1=$ severe foliar salt damage (more than $90 \%$ leaves with burn and necrosis); $2=$ moderate foliar salt damage $(90 \%$ to $50 \%) ; 3=$ slight foliar salt damage (less than 50\%); $4=$ good quality with minimal foliar salt damage; $5=$ excellent without foliar salt damage (Sun et al., 2015). Relative chlorophyll content was measured using a chlorophyll meter [Soil Plant Analysis Development (SPAD)-502; Minolta Camera Co., Osaka, Japan] at harvest. The chlorophyll contents of five mature leaves per plant were recorded, and the averaged values were recorded. Plant height (centimeters) was measured at the initiation of the experiment and at the first and second harvest. The increment in plant height was calculated as the differences between the initial height and the height at each harvest date. Relative height was calculated using an equation: height in salt treatment / height in control $\times$ $100 \%$ (Liu et al., 2017). Ten and five plants were recorded at the first and second harvest, respectively, for visual score, plant height, and SPAD reading. At both harvest dates, total leaf area per plant was recorded using a leaf area meter (LI-3100; LI-COR Biosciences, Lincoln, NE). Shoots were dried in an oven at $80^{\circ} \mathrm{C}$ for $4 \mathrm{~d}$, and shoot dry weight (DW) was determined. Relative shoot DW was calculated using the following equation: shoot DW in salt treatment / shoot DW in control $\times 100 \%$.

Experimental design and statistical analyses. The experiment used a randomized complete block design with 10 blocks for all taxa, except six blocks for $V$. $\times$ 'NCVX1'. An analysis of variance procedure was used to test the effects of salinity on the visual quality and growth data. Means separation among treatments was adjusted using Tukey's honestly significant difference or Student's $t$ test at $\alpha=0.05$. Due to the importance of visual quality and relative growth rate; visual score and relative height at both harvest dates as well as relative dry weight at the second harvest were used to conduct a cluster analysis (Liu et al., 2017). All statistical analyses were carried out using JMP (Version 13.2; SAS Institute, Cary, NC).

Table 1. Plant materials used in the study.

\begin{tabular}{ll}
\hline Taxa & \multicolumn{1}{c}{ Common name } \\
\hline Viburnum $\times$ burkwoodii & Burkwood viburnum \\
$V$. cassinoides 'SMNVCDD' & Lil' Ditty ${ }^{\circledR}$ witherod viburnum \\
$V$. dentatum 'Christom' & Blue Muffin ${ }^{\circledR}$ arrowwood viburnum \\
$V$. dentatum var. deamii 'SMVDLS' & All That Glitters ${ }^{\circledR}$ arrowwood viburnum \\
$V$. dilatatum 'Henneke' & Cardinal Candy ${ }^{\circledR}$ linden viburnum \\
$V . \times$ 'NCVX1' & Shiny Dancer ${ }^{\circledR}$ viburnum \\
$V$. nudum 'Bulk' & Brandywine ${ }^{\mathrm{TM}}$ witherod viburnum \\
$V$. opulus 'Roseum' & 'Roseum' European cranberrybush viburnum \\
$V$. plicatum var. tomentosum 'Summer Snowflake' & 'Summer Snowflake' doublefile viburnum \\
$V$. pragense 'Decker' & 'Decker' Prague viburnum \\
$V . \times$ rhytidophylloides 'Redell' & Red Balloon ${ }^{\circledR}$ lantanaphyllum viburnum \\
$V$. trilobum & Redwing ${ }^{\circledR}$ American cranberrybush viburnum \\
\hline
\end{tabular}

\section{Results and Discussion}

Visual quality. At the first harvest, all plants irrigated with saline solution at an EC of $5.0 \mathrm{dS} \cdot \mathrm{m}^{-1}$ survived (data not shown). Most plants treated with saline solution at an EC of $5.0 \mathrm{dS} \cdot \mathrm{m}^{-1}$ showed minimal or no foliar damage except $V$. cassinoides 'SMNVCDD', $V$. dilatatum 'Henneke', and $V$. plicatum var. tomentosum 'Summer Snowflake' (Table 3; Fig. 1), which did exhibit slight foliar damage. When irrigated with saline solution at an EC of $10.0 \mathrm{dS} \cdot \mathrm{m}^{-1}$, all $V$. $\times$ burkwoodii, $V$. dentatum 'Christom', $V$. dentatum var. deamii 'SMVDLS', $V$. ×'NCVX1', $V$. nudum 'Bulk', and $V$. pragense 'Decker' plants survived, but $V$. dilatatum 'Henneke', $V$. plicatum var. tomentosum 'Summer Snowflake', and $V$. trilobum showed a mortality of $60 \%$, $40 \%$, and $70 \%$, respectively. Only one of 10 $V$. cassinoides 'SMNVCDD', $V$. opulus 'Roseum', and V. xrhytidophylloides 'Redell' plants died at an EC of $10.0 \mathrm{dS} \cdot \mathrm{m}^{-1}$. In terms of foliar salt damage, $V . \times$ burkwoodii, $V$. dentatum 'Christom', $V$. dentatum var. deamii 'SMVDLS', and $V . \times$ 'NCVX1' had minimal foliar damage at an EC of 10.0 $\mathrm{dS} \cdot \mathrm{m}^{-1}$, but severe foliar damage was observed on $V$. dilatatum 'Henneke', $V$. plicatum var. tomentosum 'Summer Snowflake', and $V$. trilobum with average visual scores of 0.4 , 1.1 , and 0.4 , respectively. Other tested taxa had moderate or slight foliar damage with mean visual scores ranging from 2.3 to 3.8 .

At the second harvest, one of five $V$. dilatatum 'Henneke' and V. opulus 'Roseum' plants and two of five $V$. trilobum plants died when they were irrigated with saline solution at an EC of $5.0 \mathrm{dS} \cdot \mathrm{m}^{-1}$. Viburnum dilatatum 'Henneke' and $V$. trilobum irrigated with saline solution at an EC of $5.0 \mathrm{dS} \cdot \mathrm{m}^{-1}$ had severe foliar damage with an average visual score of 1.2 and 1.1, respectively. However, minimal or no foliar damage was observed on $V$. burkwoodii, $V$. dentatum 'Christom', $V$. dentatum var. deamii 'SMVDLS', $V$. ×'NCVX1', $V$. nudum 'Bulk', $V$. pragense 'Decker', and $V$. $\times$ rhytidophylloides 'Redell'. On the other hand, at an EC of $10.0 \mathrm{dS} \cdot \mathrm{m}^{-1}$, all $V$. dentatum 'Christom', $V$. dilatatum 'Henneke', V. plicatum var. tomentosum 'Summer Snowflake', and V. trilobum plants died. Four of five plants died for $V$. nudum

Table 2. The mineral contents and sodium absorption ratio (SAR) of tap water, nutrient solution, and saline solution used in the study.

\begin{tabular}{|c|c|c|c|c|}
\hline \multirow[b]{2}{*}{ Item $^{2}$} & \multirow[b]{2}{*}{ Tap water } & \multirow[b]{2}{*}{ Nutrient solutiony } & \multicolumn{2}{|c|}{ Saline solution $^{\mathrm{x}}$} \\
\hline & & & $5.0 \mathrm{dS} \cdot \mathrm{m}^{-1}$ & $10.0 \mathrm{dS} \cdot \mathrm{m}^{-1}$ \\
\hline $\mathrm{Mg}^{2+}\left(\mathrm{mg} \cdot \mathrm{L}^{-1}\right)$ & 17.3 & 35.8 & 38.9 & 33.9 \\
\hline $\mathrm{Cl}^{-}\left(\mathrm{mg} \cdot \mathrm{L}^{-1}\right)$ & 3.4 & 4.3 & 1270.0 & 3120.0 \\
\hline $\mathrm{B}\left(\mathrm{mg} \cdot \mathrm{L}^{-1}\right)$ & 0 & 0.19 & 0.16 & 0.18 \\
\hline SAR & 0.04 & 0.05 & 5.40 & 9.89 \\
\hline
\end{tabular}

${ }^{2}$ Calcium $\left(\mathrm{Ca}^{2+}\right)$, magnesium $\left(\mathrm{Mg}^{2+}\right)$, sodium $\left(\mathrm{Na}^{+}\right)$, sulphate $\left(\mathrm{SO}_{4}^{2-}\right)$, chloride $\left(\mathrm{Cl}^{-}\right)$, and boron $(\mathrm{B})$ ions.

${ }^{\mathrm{y}}$ The nutrient solution at an electrical conductivity of $1.3 \mathrm{dS} \cdot \mathrm{m}^{-1}$ was made by mixing $0.8 \mathrm{~g} \cdot \mathrm{L}^{-1} 15 \mathrm{~N}-2.2 \mathrm{P}-12.5 \mathrm{~K}$ water-soluble fertilizer (Peter Excel $15-5-15$ Cal-Mag Special) in tap water.

${ }^{\mathrm{x}}$ Sodium chloride $(\mathrm{NaCl})$ and dihydrate calcium chloride $\left(\mathrm{CaCl}_{2} \cdot 2 \mathrm{H}_{2} \mathrm{O}\right)$ were used to prepare saline solution. The nutrient solution was spiked with $\mathrm{NaCl}$ at 0.92 $\mathrm{g} \cdot \mathrm{L}^{-1}$ and $\mathrm{CaCl}_{2} \cdot 2 \mathrm{H}_{2} \mathrm{O}$ at $1.17 \mathrm{~g} \cdot \mathrm{L}^{-1}$ to make the saline solution at an $\mathrm{EC}$ of $5.0 \mathrm{dS} \cdot \mathrm{m}^{-1}$, whereas the nutrient solution was supplemented with $2.27 \mathrm{~g} \cdot \mathrm{L}^{-1} \mathrm{NaCl}$ and $2.88 \mathrm{~g} \cdot \mathrm{L}^{-1} \mathrm{CaCl}_{2} \cdot 2 \mathrm{H}_{2} \mathrm{O}$ to create the saline solution at an electrical conductivity of $10.0 \mathrm{dS} \cdot \mathrm{m}^{-1}$. 
Table 3. Visual score of 12 viburnum taxa irrigated with a nutrient solution [electrical conductivity $(\mathrm{EC})=1.3 \mathrm{dS} \cdot \mathrm{m}^{-1}$; control] or a saline solution [EC $=5.0$ $\mathrm{dS} \cdot \mathrm{m}^{-1}$ (EC 5) or $10.0 \mathrm{dS} \cdot \mathrm{m}^{-1}$ (EC 10)] in a greenhouse. ${ }^{\mathrm{z}}$

\begin{tabular}{|c|c|c|c|c|c|c|}
\hline \multirow[b]{3}{*}{ Taxa } & \multicolumn{6}{|c|}{ Visual score $(0-5 \text { scale })^{y}$} \\
\hline & \multicolumn{3}{|c|}{ First harvest } & \multicolumn{3}{|c|}{ Second harvest } \\
\hline & Control & EC 5 & $\overline{\mathrm{EC} 10}$ & Control & EC 5 & EC 10 \\
\hline Viburnum $\times$ burkwoodii & $5.0 \mathrm{a}^{\mathrm{x}}$ & $5.0 \mathrm{a}$ & $4.9 \mathrm{~b}$ & $5.0 \mathrm{a}$ & $5.0 \mathrm{a}$ & $2.9 \mathrm{~b}$ \\
\hline V. cassinoides 'SMNVCDD' & $4.7 \mathrm{a}$ & $3.9 \mathrm{a}$ & $2.3 \mathrm{~b}$ & $4.7 \mathrm{a}$ & $2.8 \mathrm{~b}$ & $0.3 \mathrm{c}$ \\
\hline V. dentatum 'Christom' & $5.0 \mathrm{a}$ & $5.0 \mathrm{a}$ & $4.1 \mathrm{~b}$ & $4.8 \mathrm{a}$ & $4.0 \mathrm{~b}$ & $0.0 \mathrm{c}$ \\
\hline V. dentatum var. deamii 'SMVDLS' & $5.0 \mathrm{a}$ & $4.9 \mathrm{a}$ & $4.0 \mathrm{~b}$ & $5.0 \mathrm{a}$ & $4.2 \mathrm{a}$ & $1.3 \mathrm{~b}$ \\
\hline V. dilatatum 'Henneke' & $4.9 \mathrm{a}$ & $3.5 \mathrm{~b}$ & $0.4 \mathrm{c}$ & $3.5 \mathrm{a}$ & $1.2 \mathrm{~b}$ & $0.0 \mathrm{~b}$ \\
\hline$V . \times{ }^{\prime N C V X} 1 '$ & $5.0 \mathrm{a}$ & $5.0 \mathrm{a}$ & $4.6 \mathrm{~b}$ & $4.7 \mathrm{a}$ & $4.6 \mathrm{a}$ & $3.4 \mathrm{~b}$ \\
\hline V. nudum 'Bulk' & $5.0 \mathrm{a}$ & $4.9 \mathrm{a}$ & $3.6 \mathrm{~b}$ & $5.0 \mathrm{a}$ & $4.5 \mathrm{a}$ & $0.7 \mathrm{~b}$ \\
\hline V. opulus 'Roseum' & $5.0 \mathrm{a}$ & $4.9 \mathrm{a}$ & $2.8 \mathrm{~b}$ & $4.1 \mathrm{a}$ & $2.4 \mathrm{ab}$ & $0.6 \mathrm{~b}$ \\
\hline$V$. plicatum var. tomentosum 'Summer Snowflake' & $5.0 \mathrm{a}$ & $3.8 \mathrm{~b}$ & $1.1 \mathrm{c}$ & $3.8 \mathrm{a}$ & $2.6 \mathrm{~b}$ & $0.0 \mathrm{c}$ \\
\hline$V$. pragense 'Decker' & $5.0 \mathrm{a}$ & $4.9 \mathrm{a}$ & $3.8 \mathrm{~b}$ & $4.9 \mathrm{a}$ & $4.4 \mathrm{a}$ & $1.2 \mathrm{~b}$ \\
\hline$V . \times$ rhytidophylloides 'Redell' & $5.0 \mathrm{a}$ & $4.9 \mathrm{a}$ & $3.3 \mathrm{~b}$ & $4.8 \mathrm{a}$ & $4.6 \mathrm{a}$ & $0.2 \mathrm{~b}$ \\
\hline V. trilobum & $5.0 \mathrm{a}$ & $4.5 \mathrm{a}$ & $0.4 \mathrm{~b}$ & $4.9 \mathrm{a}$ & $1.1 \mathrm{~b}$ & $0.0 \mathrm{~b}$ \\
\hline
\end{tabular}

${ }^{\mathrm{z}}$ Plants were harvested after the fourth irrigation (first harvest, 4 weeks after the initiation of treatment) and eighth irrigation (second harvest, 9 weeks after the initiation of treatment).

${ }^{\mathrm{y}} 0=$ dead; $1=$ severe foliar salt damage (more than $90 \%$ leaves with burn and necrosis); $2=$ moderate foliar salt damage ( $90 \%$ to $50 \%$ ); $3=$ slight foliar salt damage (less than $50 \%) ; 4=$ good quality with minimal foliar salt damage; and $5=$ excellent without foliar salt damage (Sun et al., 2015).

${ }^{x}$ Means with the same lowercase letters within a row and harvest date are not significantly different among treatments by Tukey's honestly significant difference at $\alpha=0.05$.

'Bulk' and $V$. Xrhytidophylloides 'Redell'. Three of five plants died for $V$. cassinoides 'SMNVCDD', $V$. opulus 'Roseum', and $V$.

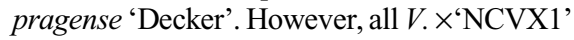
plants, four of five $V$. $\times$ burkwoodii plants, and three of five $V$. dentatum var. deamii 'SMVDLS' plants survived. Most viburnum plants irrigated with saline solution at an EC of $10.0 \mathrm{dS} \cdot \mathrm{m}^{-1}$ had severe foliar damage except $V$. $\times$ burkwoodii and $V$. $\times$ 'NCVX1' that had moderate and slight foliar damage, respectively, with an average visual score of 2.9 and 3.4.

These results indicate that saline irrigation solution imposed salinity stress on viburnum taxa tested in this study, and the degree of foliar damage was dependent on the salinity levels of irrigation solution and the length of the exposure to salinity stress. Results also imply that the tested viburnum taxa exhibited various degrees of salinity tolerance. Zimmerman et al. (2005) reported that $V$. lantana (wayfaring tree viburnum) had increased bud injury with increasing $\mathrm{NaCl}$ concentration. Viburnum tinus irrigated with saline solution at an EC of $6.0 \mathrm{dS} \cdot \mathrm{m}^{-1}$ for more than 6 months exhibited significant salt damage including necrotic lesions, wilting, and curling leaves with $24 \%$ abscised leaves compared with the control $\left(\mathrm{EC}=2.0 \mathrm{dS} \cdot \mathrm{m}^{-1}\right)$ (Bañón et al., 2012a, 2012b). However, Cassaniti et al. (2009) found no foliar damage on $V$. lucidum treated with $70 \mathrm{~mm} \mathrm{NaCl}$ solution at an EC of $7.4 \mathrm{dS} \cdot \mathrm{m}^{-1}$ for $120 \mathrm{~d}$ and classified it as a salinity-tolerant plant. Viburnum dentatum 'Christom' and V. dentatum var. deamii 'SMVDLS' belong to the same species and exhibited similar salinity tolerance in terms of visual quality. However, Cai et al. (2014) reported that salinity tolerance varied among 18 garden rose (Rosa hybrida) cultivars, although they are within the same genus.

Foliar damage observed on viburnum taxa might result from salt accumulation in the growing substrate. Salts accumulated in the substrate could be measured indirectly by pour-through technique (Cavins et al., 2008) and directly by saturated soil paste technique (Gavlak et al., 1994). Substrate salinity levels in this study gradually increased during the experiment (Fig. 2). It has been observed that EC values of the leachate solution were greater than that of the respective treatment solution at the fourth irrigation with nutrient solution or saline solution at an EC of 5.0 $\mathrm{dS} \cdot \mathrm{m}^{-1}$ and at the third irrigation of saline solution at an EC of $10.0 \mathrm{dS} \cdot \mathrm{m}^{-1}$. These results indicate saturation of the cation exchange sites within the substrate (Taiz et al., 2015). For those plants irrigated with saline solution at an EC of 5.0 or $10.0 \mathrm{dS} \cdot \mathrm{m}^{-1}$, EC values of the leachate solution increased from 2.1 to $8.2 \mathrm{dS} \cdot \mathrm{m}^{-1}$ and 4.1 to $15.5 \mathrm{dS} \cdot \mathrm{m}^{-1}$, respectively. However, EC values of the leachate solution rose from 0.9 to $1.9 \mathrm{dS} \cdot \mathrm{m}^{-1}$ for those plants irrigated with the nutrient solution. More directly, EC values of the soil extraction were greater when saline solution at an EC of 5.0 or $10.0 \mathrm{dS} \cdot \mathrm{m}^{-1}$ was applied compared with the control at both harvest dates (all $P$ values $<0.0001$ ). In addition, EC values of the soil extraction were greater at the second harvest than the first (all $P$ values $<0.006$ ) (Fig. 3). Aesthetic appearance is a major concern for the sale and marketing of landscape plants. Therefore, it is better to reduce foliar salt damage during nursery production. Best management practices should be adopted to alleviate salt accumulation when poor quality water is used for irrigation. Possible solutions include adding low cation exchange capacity components such as perlite and bark in the potting mix and increasing leachate fraction (Altland et al., 2014).

Plant height. At the first harvest, all viburnum taxa irrigated with saline solution at an EC of $5.0 \mathrm{dS} \cdot \mathrm{m}^{-1}$ had similar plant height to the plants in the control, except $V$. $\times$ rhytidophylloides 'Redell' and $V$. trilobum, which exhibited a reduction of $42 \%$ and $58 \%$, respectively, compared with the control (Table 4). Saline solution at an EC of 10.0 $\mathrm{dS} \cdot \mathrm{m}^{-1}$ further reduced plant height by $34 \%$ to $92 \%$ in all taxa except $V$. $\times$ burkwoodii, $V$. dentatum var. deamii 'SMVDLS', and $V$. $\times$ 'NCVX1', compared with the control. At the second harvest, saline solution at an EC of $5.0 \mathrm{dS} \cdot \mathrm{m}^{-1}$ reduced the plant height of $V$. nudum 'Bulk' and $V$. Xrhytidophylloides 'Redell' by $30 \%$ and $50 \%$, respectively, compared with the control. Viburnum trilobum irrigated with saline solution at an EC of $5.0 \mathrm{dS} \cdot \mathrm{m}^{-1}$ had decreased plant height by $65 \%$ compared with the control $(P=0.07)$. The plant height of $V$. $\times$ burkwoodii, $V$. nudum 'Bulk', V. pragense 'Decker', and $V$. $\times$ rhytidophylloides 'Redell' irrigated with saline solution at an EC of $10.0 \mathrm{dS} \cdot \mathrm{m}^{-1}$ were $52 \%, 70 \%, 60 \%$, and $76 \%$, respectively, shorter than that in the control. Plant height of $V$. dentatum var. deamii 'SMVDLS' and $V$. opulus 'Roseum' irrigated with saline solution at an EC of $10.0 \mathrm{dS} \cdot \mathrm{m}^{-1}$ were $72 \%(P=$ $0.08)$ and $79 \%(P=0.06)$, shorter than the control, respectively. Although plant height of $V$. cassinoides 'SMNVCDD' irrigated with saline solution at an EC of $10.0 \mathrm{dS} \cdot \mathrm{m}^{-1}$ decreased by $71 \%$ comparted with the control, their differences were not statistically significant. This may be the result of large variations measured among surviving plants.

When plants are susceptible to salinity stress, saline water irrigation causes severe growth reduction (Cassaniti et al., 2009). The negative effect of salinity stress has previously been reported on viburnum plant growth. Cirillo et al. (2019) observed that $V$. lucidum canopy size was reduced by $22 \%$ and $26 \%$ when irrigated with $\mathrm{NaCl}-$ or $\mathrm{CaCl}_{2}$ spiked solution at an $\mathrm{EC} \approx 11.0 \mathrm{dS} \cdot \mathrm{m}^{-1}$, compared with the control (nutrient solution at an EC of $2.0 \mathrm{dS} \cdot \mathrm{m}^{-1}$ ). In another study, $V$. lucidum irrigated with $\mathrm{NaCl}$-spiked solution at an EC of $20.5 \mathrm{dS} \cdot \mathrm{m}^{-1}$ had reductions in apical shoot length ranging from $66 \%$ to $81 \%$ and in lateral shoot length from $60 \%$ to $77 \%$ during the growing cycle (at 67, 90, and $103 \mathrm{~d}$ after treatment), compared with the control $\left(\mathrm{EC}=1.6 \mathrm{dS} \cdot \mathrm{m}^{-1}\right)($ Cirillo et al., 2016). Saline 


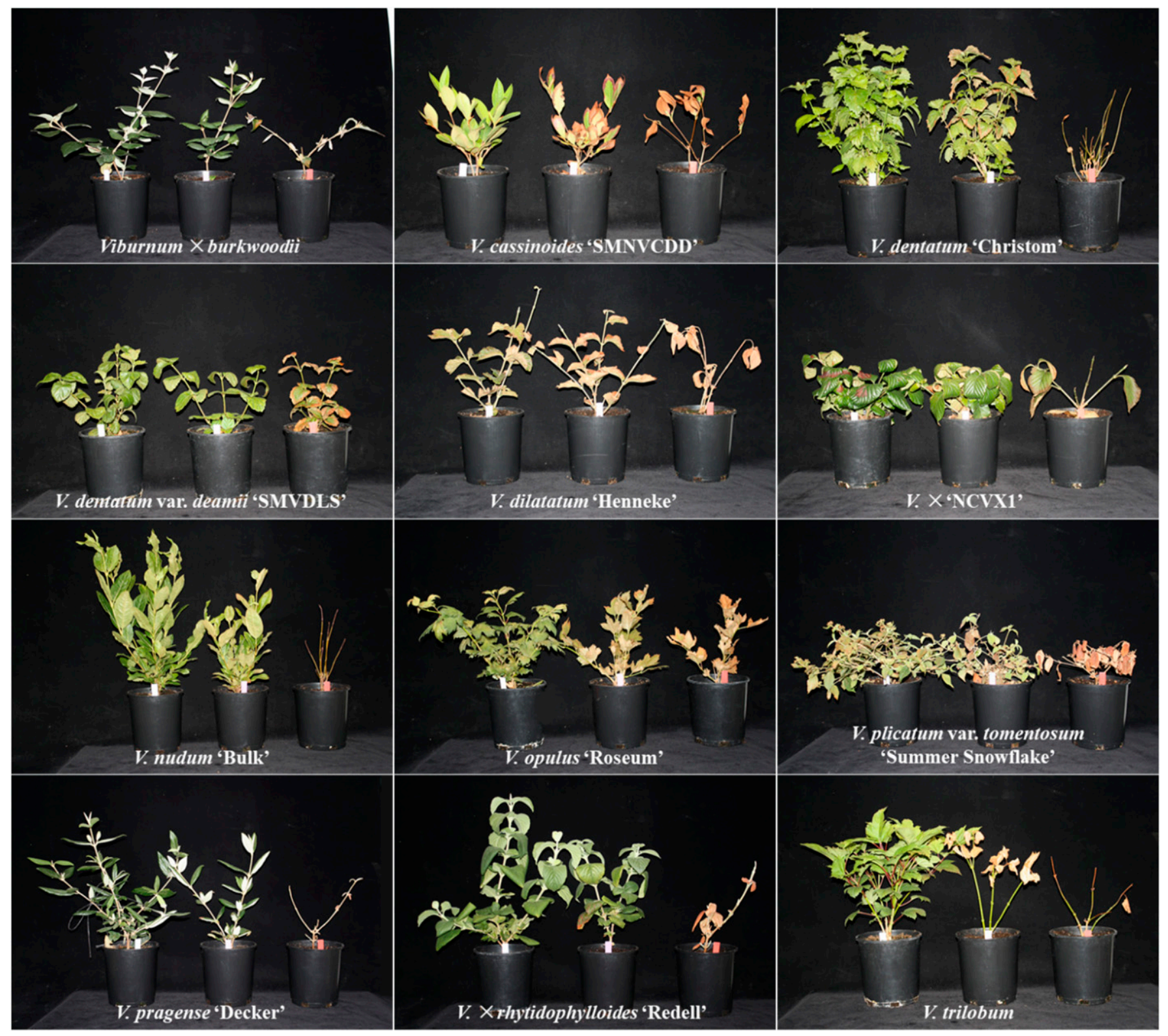

Fig. 1. Twelve viburnum taxa irrigated with a nutrient solution at an electrical conductivity (EC) of $1.3 \mathrm{dS} \cdot \mathrm{m}^{-1}$ (Control) or saline solution at an EC of $5.0 \mathrm{dS} \cdot \mathrm{m}^{-1}$ (EC 5) or $10.0 \mathrm{dS} \cdot \mathrm{m}^{-1}$ (EC 10) at 8 weeks after initiation of treatment. From left to right: control, EC 5, and EC 10.

solution at an EC of $6.0 \mathrm{dS} \cdot \mathrm{m}^{-1}$ resulted in a $7 \%$ reduction in plant height of $V$. tinus after 24 weeks of treatment, compared with the control $\left(\mathrm{EC}<0.9 \mathrm{dS} \cdot \mathrm{m}^{-1}\right)$ (Gómez-Bellot et al., 2018). These findings point to a situation where the negative effect of salinity on plant growth and development could increase the time, fertilizer and labor required to grow plants to a marketable size and quality. Therefore, selecting cultivars/genotypes with better salinity tolerance is important for the Green Industry.

Leaf area. At the first harvest, saline solution at an EC of $5.0 \mathrm{dS} \cdot \mathrm{m}^{-1}$ reduced leaf area by $50 \%$ for $V$. plicatum var. tomentosum 'Summer Snowflake' compared with the control (Table 5), but this was not the case for the other eleven viburnum taxa. At an EC of $10.0 \mathrm{dS} \cdot \mathrm{m}^{-1}$, leaf area of $V$. cassinoides 'SMNVCDD', $V$. dentatum 'Christom', $V$. nudum 'Bulk', $V$. opulus 'Roseum', and $V$. plicatum var. tomentosum 'Summer Snowflake' decreased by $32 \%, 32 \%, 37 \%, 31 \%$, and $62 \%$, respectively, compared with the control. At the second harvest, saline solution at an EC of $5.0 \mathrm{dS} \cdot \mathrm{m}^{-1}$ reduced the leaf area of $V$. $\times$ burkwoodii, $V$. plicatum var. tomentosum 'Summer Snowflake', V. ×rhytidophylloides 'Redell', and $V$. trilobum by $31 \%, 32 \%, 44 \%$, and $73 \%$, respectively, compared with the control. When irrigated with saline solution at an EC of $10.0 \mathrm{dS} \cdot \mathrm{m}^{-1}$, the leaf area was decreased by $45 \%, 58 \%, 63 \%$, and $84 \%$ for $V$. ×burkwoodii, $V$. dentatum var. deamii 'SMVDLS', $V$. pragense 'Decker', and $V$. $\times$ rhytidophylloides 'Redell', respectively, compared with the control. In previous studies, $V$. tinus had decreased leaf area by $48 \%$ when irrigated with saline solution at an EC of $6.0 \mathrm{dS} \cdot \mathrm{m}^{-1}$, compared with a treatment at an EC of $2.0 \mathrm{dS} \cdot \mathrm{m}^{-1}$ (Bañón et al., 2012a, $2012 \mathrm{~b}$ ). Leaf area of $V$. lucidum was decreased when irrigated with $\mathrm{NaCl}-$ or $\mathrm{CaCl}_{2-}$ spiked solution at an $\mathrm{EC}$ of $\approx 11.0 \mathrm{dS} \cdot \mathrm{m}^{-1}$ and $\mathrm{NaCl}$-spiked solution at an EC of $20.5 \mathrm{dS} \cdot \mathrm{m}^{-1}$ by $31 \%, 60 \%$, and $48 \%$ (Cirillo et al., 2016 , 2019). Leaf area was decreased by $31 \%$ and $60 \%$ when $V$. lucidum plants were irrigated with $\mathrm{NaCl}$-spiked and $\mathrm{CaCl}_{2}$-spiked solution at an $\mathrm{EC} \approx 11.0 \mathrm{dS} \cdot \mathrm{m}^{-1}$, respectively (Cirillo et al., 2019) and reduced by $48 \%$ with $\mathrm{NaCl}$ spiked solution at an EC of $20.5 \mathrm{dS} \cdot \mathrm{m}^{-1}$ (Cirillo et al., 2016).

Shoot $D W$. At the first harvest, the shoot DW of $V$. cassinoides 'SMNVCDD' and $V$. plicatum var. tomentosum 'Summer Snowflake' irrigated with saline solution at an EC of $5.0 \mathrm{dS} \cdot \mathrm{m}^{-1}$ reduced by $20 \%$ and $40 \%$, respectively, compared with the control (Table 6). No change in shoot DW was 


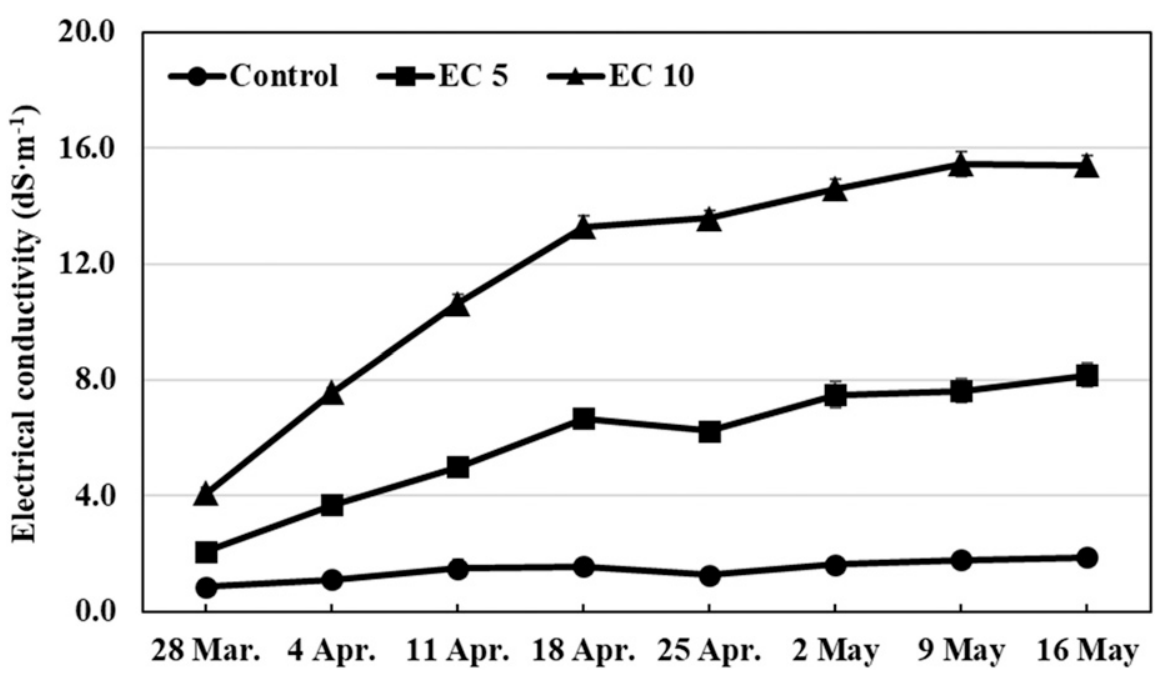

Fig. 2. Leachate electrical conductivity (EC) recorded after 12 viburnum taxa were irrigated with a nutrient solution at an EC of $1.3 \mathrm{dS} \cdot \mathrm{m}^{-1}$ (Control) or saline solution at an EC of $5.0 \mathrm{dS} \cdot \mathrm{m}^{-1}$ (EC 5) or $10.0 \mathrm{dS} \cdot \mathrm{m}^{-1}$ (EC 10). Vertical bars indicate SE of 12 samples.

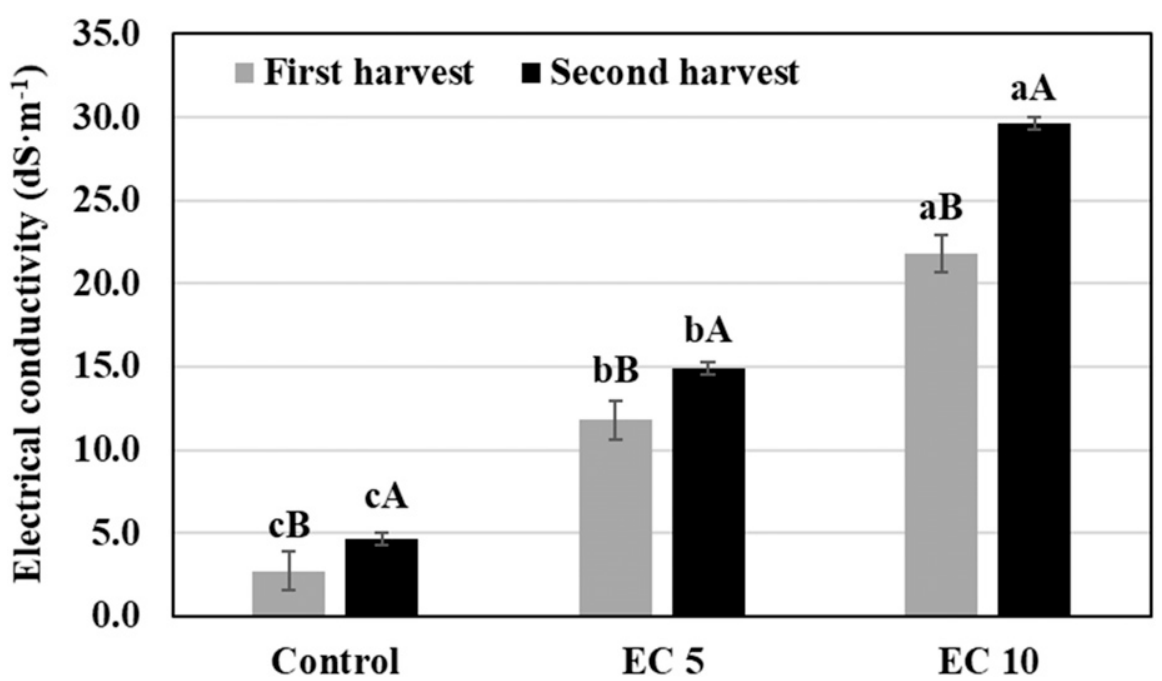

Fig. 3. Electrical conductivity (EC) of the soil extraction recorded for all 12 viburnum taxa irrigated with a nutrient solution at an EC of $1.3 \mathrm{dS} \cdot \mathrm{m}^{-1}$ (Control) or saline solution at an EC of $5.0 \mathrm{dS} \cdot \mathrm{m}^{-1}$ (EC 5) or $10.0 \mathrm{dS} \cdot \mathrm{m}^{-1}$ (EC 10). Plants were harvested on 27 Apr. (first harvest) and 31 May 2019 (second harvest). Vertical bars indicate standard errors of 33 and 36 samples, respectively, for the first and second harvest. Viburnum $\times$ 'NCVX1' plants were harvested only once. Same lowercase letters above columns within the harvest date represent no significance among treatments by Tukey's honestly significant difference at $\alpha=0.05$. Same uppercase letters above columns within treatment represent no significance between two harvest dates by Student's $t$ test at $\alpha=0.05$.

observed for other viburnum taxa. Saline solution at an EC of $10.0 \mathrm{dS} \cdot \mathrm{m}^{-1}$ reduced the shoot DW of $V$. cassinoides 'SMNVCDD', $V$. dentatum 'Christom', $V$. dilatatum 'Henneke', $V$. plicatum var. tomentosum 'Summer Snowflake', and $V$. trilobum by $27 \%, 39 \%, 33 \%$, $49 \%$, and $60 \%$, respectively, compared with the control. Also, compared with the control, shoot DW decreased by $33 \%$ and $22 \%$, respectively, for $V$. dentatum var. deamii 'SMVDLS' $(P=0.07)$ and $V$. pragense 'Decker' $(P=0.09)$ irrigated with saline solution at an EC of 10.0 $\mathrm{dS} \cdot \mathrm{m}^{-1}$.

At the second harvest, the shoot DW of $V$. $\times$ rhytidophylloides 'Redell' and $V$. trilobum irrigated with saline solution at an EC of 5.0 $\mathrm{dS} \cdot \mathrm{m}^{-1}$ decreased by $38 \%$ and $65 \%$, respec- tively, compared with the control. Despite no statistical difference, saline solution at an EC of $5.0 \mathrm{dS} \cdot \mathrm{m}^{-1}$ decreased the shoot DW by $4 \%$ to $46 \%$ for other remaining viburnum taxa, compared with the control. At an EC of 10.0 $\mathrm{dS} \cdot \mathrm{m}^{-1}, V$. dentatum var. deamii 'SMVDLS', $V$. nudum 'Bulk', $V$. opulus 'Roseum', $V$. pragense 'Decker', and $V$. ×rhytidophylloides 'Redell' had reduced shoot DW of $59 \%, 69 \%$, $37 \%$, 56\%, and $73 \%$, respectively, compared with the control. Despite no statistical difference, saline solution at an EC of $10.0 \mathrm{dS} \cdot \mathrm{m}^{-1}$ decreased shoot DW of $V$. cassinoides 'SMNVCDD' by $51 \%(P=0.08), V$. $\times$ 'NCVX1' by $25 \%(P=0.06)$, and $V$. $\times$ burkwoodii by $24 \%(P=0.3)$. Relative growth rate, an indicator associated with plant dry weight, of $V$. lucidum plants decreased by $10 \%$ when irrigated with saline solution at an EC of either 4.4 or $7.4 \mathrm{dS} \cdot \mathrm{m}^{-1}$ compared with those plants at an EC of 1.4 $\mathrm{dS} \cdot \mathrm{m}^{-1}$ (Cassaniti et al., 2009). Shoot DW decreased by $32 \%$ and $24 \%$ for $V$. lucidum irrigated with $\mathrm{NaCl}$-spiked and $\mathrm{CaCl}_{2}$-spiked solution at an EC around $11.0 \mathrm{dS} \cdot \mathrm{m}^{-1}$, respectively (Cirillo et al., 2019) and reduced by $37 \%$ with $\mathrm{NaCl}$-spiked solution at an EC of $20.5 \mathrm{dS} \cdot \mathrm{m}^{-1}$ (Cirillo et al., 2016). Similarly, Sifola et al. (2017) reported that $V$. lucidum had decreased leaf DW by $39 \%$ when irrigated with $\mathrm{NaCl}$-spiked solution at an EC of $20.5 \mathrm{dS} \cdot \mathrm{m}^{-1}$.

Relative chlorophyll content. At the first harvest, saline solution at an EC of $5.0 \mathrm{dS} \cdot \mathrm{m}^{-1}$ did not affect the relative chlorophyll content of all viburnum taxa (Table 7). However, at an EC of $10.0 \mathrm{dS} \cdot \mathrm{m}^{-1}$, relative chlorophyll content of $V$. cassinoides 'SMNVCDD' and $V$. opulus 'Roseum' decreased compared with the control. At the second harvest, when irrigated with saline solution at an EC of 5.0 $\mathrm{dS} \cdot \mathrm{m}^{-1}, V . \times$ burkwoodii and $V$. trilobum had reduced SPAD readings, but $V$. dentatum 'Christom' had greater SPAD readings compared with the control. At an EC of 10.0 $\mathrm{dS} \cdot \mathrm{m}^{-1}$, relative chlorophyll content of $V$. pragense 'Decker' and $V$. $\times$ rhytidophylloides 'Redell' decreased, but $V$. ×burkwoodii had increased SPAD readings compared with plants irrigated with saline solution at an EC of $5.0 \mathrm{dS} \cdot \mathrm{m}^{-1}$. In general, most plants have decreased relative chlorophyll content under salinity stress (Cai et al., 2014; Liu et al., 2017). Gómez-Bellot et al. (2018) also reported that $V$. tinus treated with saline solution at an EC of $6.0 \mathrm{dS} \cdot \mathrm{m}^{-1}$ had decreased relative chlorophyll content. Salinity stress was also found to reduce the relative chlorophyll content of $V$. lucidum by $35 \%$ at an EC of $20.5 \mathrm{dS} \cdot \mathrm{m}^{-1}$ compared with the control $\left(\mathrm{EC}=1.6 \mathrm{dS} \cdot \mathrm{m}^{-1}\right)$ and decrease by $22 \%$ and $23 \%$ with $\mathrm{NaCl}$-spiked and $\mathrm{CaCl}_{2}$-spiked solution at an $\mathrm{EC} \approx 11.0 \mathrm{dS} \cdot \mathrm{m}^{-1}$, respectively, compared with the control $\left(\mathrm{EC}=2.0 \mathrm{dS} \cdot \mathrm{m}^{-1}\right)$ (Cirillo et al., 2016, 2019). However, in rare cases, plants increase relative chlorophyll content under salinity stress as a tolerance mechanism to maintain photosynthesis capacity (Shah et al., 2017). Wu et al. (2016) reported that there was a $9 \%$ increase in relative chlorophyll content of Pavonia lasiopetala (rock rose) when irrigated with saline solution at an EC of $10.0 \mathrm{dS} \cdot \mathrm{m}^{-1}$ compared with the control $\left(\mathrm{EC}=1.2 \mathrm{dS} \cdot \mathrm{m}^{-1}\right)$. In our study, the chlorophyll content of $V$. $\times$ burkwoodii and $V$. dentatum 'Christom' increased under saline environment, which might result from the change in leaf structure. Gómez-Bellot et al. (2015) found that the leaf thickness of $V$. tinus grown with saline solution increased with thicker mesophyll and less intercellular space. As salinity-induced compactness of leaf cells leads to more pigments per area, the chlorophyll content would increase (Shah et al., 2017). Increased SPAD readings observed in the leaves of $V$. $\times$ burkwoodii and $V$. dentatum 'Christom' indicate that leaf structure change might 
Table 4. Plant height increment of 12 viburnum taxa irrigated with a nutrient solution [electrical conductivity $(\mathrm{EC})=1.3 \mathrm{dS} \cdot \mathrm{m}^{-1} ;$ control] or a saline solution $[\mathrm{EC}=$ $5.0 \mathrm{dS} \cdot \mathrm{m}^{-1}$ (EC 5) or $10.0 \mathrm{dS} \cdot \mathrm{m}^{-1}$ (EC 10)] in a greenhouse. ${ }^{\mathrm{z}}$

\begin{tabular}{|c|c|c|c|c|c|c|}
\hline \multirow{2}{*}{ Taxa } & \multicolumn{6}{|c|}{ Plant ht increment $(\mathrm{cm})$} \\
\hline & \multicolumn{3}{|c|}{ First harvest } & \multicolumn{3}{|c|}{ Second harvest } \\
\hline Viburnum $\times$ burkwoodii & $9.2 \mathrm{a}^{\mathrm{y}}$ & $10.0 \mathrm{a}$ & $6.8 \mathrm{a}$ & $13.9 \mathrm{a}$ & $14.0 \mathrm{a}$ & $6.7 \mathrm{~b}$ \\
\hline V. dentatum 'Christom' & $5.3 \mathrm{a}$ & $2.8 \mathrm{ab}$ & $0.8 \mathrm{~b}$ & $12.7 \mathrm{a}$ & $5.7 \mathrm{a}$ & $-^{x}$ \\
\hline V. dentatum var. deamii 'SMVDLS' & $8.0 \mathrm{a}$ & $7.1 \mathrm{a}$ & $4.6 \mathrm{a}$ & $15.3 \mathrm{a}$ & $11.8 \mathrm{a}$ & $4.3 \mathrm{a}$ \\
\hline V. dilatatum 'Henneke' & $17.2 \mathrm{a}$ & $14.1 \mathrm{ab}$ & $5.5 \mathrm{~b}$ & $20.4 \mathrm{a}$ & $15.9 \mathrm{a}$ & - \\
\hline$V . \times{ }^{\prime N C V X} 1{ }^{\prime}$ & $1.5 \mathrm{a}$ & $1.1 \mathrm{a}$ & $1.7 \mathrm{a}$ & $1.3 \mathrm{a}$ & $1.9 \mathrm{a}$ & $2.2 \mathrm{a}$ \\
\hline V. plicatum var. tomentosum 'Summer Snowflake' & $5.0 \mathrm{a}$ & $4.0 \mathrm{ab}$ & $1.3 \mathrm{~b}$ & $8.0 \mathrm{a}$ & $5.2 \mathrm{a}$ & - \\
\hline V. pragense 'Decker' & $13.5 \mathrm{a}$ & $13.0 \mathrm{a}$ & $8.9 \mathrm{~b}$ & $22.3 \mathrm{a}$ & $21.2 \mathrm{a}$ & $9.0 \mathrm{~b}$ \\
\hline V. Xrhytidophylloides 'Redell' & $15.9 \mathrm{a}$ & $9.2 \mathrm{~b}$ & $5.8 \mathrm{~b}$ & $27.7 \mathrm{a}$ & $13.9 \mathrm{~b}$ & $6.7 \mathrm{~b}$ \\
\hline V. trilobum & $12.1 \mathrm{a}$ & $5.1 \mathrm{~b}$ & $1.0 \mathrm{c}$ & $22.8 \mathrm{a}$ & $8.0 \mathrm{a}$ & - \\
\hline
\end{tabular}

${ }^{\mathrm{z}}$ Plant height increment was calculated as the difference between initial height and the height at each harvest date. Plants were harvested after the fourth irrigation (first harvest, 4 weeks after the initiation of treatment) and eighth irrigation (second harvest, 9 weeks after the initiation of treatment).

${ }^{y}$ Means with the same lowercase letters within a row and harvest date are not significantly different among treatments by Tukey's honestly significant difference or between treatments by Student's $t$ test at $\alpha=0.05$.

${ }^{\mathrm{x}}$ Data were not collected due to plant death.

Table 5. Leaf area of 12 viburnum taxa irrigated with a nutrient solution [electrical conductivity $(\mathrm{EC})=1.3 \mathrm{dS} \cdot \mathrm{m}^{-1}$; control] or a saline solution [EC $=5.0 \mathrm{dS} \cdot \mathrm{m}^{-1}$ (EC 5) or $\left.10.0 \mathrm{dS} \cdot \mathrm{m}^{-1}(\mathrm{EC} 10)\right]$ in a greenhouse. ${ }^{z}$

\begin{tabular}{|c|c|c|c|c|c|c|}
\hline \multirow[b]{3}{*}{ Таха } & \multicolumn{6}{|c|}{ Leaf area $\left(\mathrm{cm}^{2}\right)$} \\
\hline & \multicolumn{3}{|c|}{ First harvest } & \multicolumn{3}{|c|}{ Second harvest } \\
\hline & Control & EC 5 & EC 10 & Control & EC 5 & EC 10 \\
\hline$\overline{\text { Viburnum } \times \text { burkwoodii }}$ & $356.8 \mathrm{a}^{\mathrm{y}}$ & $351.2 \mathrm{a}$ & $363.8 \mathrm{a}$ & $563.2 \mathrm{a}$ & $389.8 \mathrm{~b}$ & $307.6 \mathrm{~b}$ \\
\hline V. cassinoides 'SMNVCDD' & $551.6 \mathrm{a}$ & $476.6 \mathrm{a}$ & $376.1 \mathrm{~b}$ & $579.4 \mathrm{a}$ & $512.4 \mathrm{a}$ & $-^{x}$ \\
\hline V. dentatum 'Christom' & $844.8 \mathrm{a}$ & $726.0 \mathrm{a}$ & $577.6 \mathrm{~b}$ & $1420.6 \mathrm{a}$ & $832.6 \mathrm{a}$ & - \\
\hline V. dentatum var. deamii 'SMVDLS' & $487.2 \mathrm{a}$ & $412.8 \mathrm{a}$ & $354.2 \mathrm{a}$ & $734.4 \mathrm{a}$ & $522.0 \mathrm{ab}$ & $309.8 \mathrm{~b}$ \\
\hline V. dilatatum 'Henneke' & $453.6 \mathrm{a}$ & $626.8 \mathrm{a}$ & - & $713.9 \mathrm{a}$ & $522.1 \mathrm{a}$ & - \\
\hline$V . \times{ }^{\prime} \mathrm{NCVX} 1{ }^{\prime}$ & Iw & 1 & 1 & $1244.2 \mathrm{a}$ & $973.5 \mathrm{a}$ & $785.6 \mathrm{a}$ \\
\hline V. nudum 'Bulk' & $512.4 \mathrm{a}$ & $605.2 \mathrm{a}$ & $324.6 \mathrm{~b}$ & $1339.8 \mathrm{a}$ & $1069.0 \mathrm{a}$ & $157.2 \mathrm{a}$ \\
\hline V. opulus 'Roseum' & $682.4 \mathrm{a}$ & $554.4 \mathrm{ab}$ & $471.6 \mathrm{~b}$ & $713.0 \mathrm{a}$ & $617.0 \mathrm{a}$ & - \\
\hline V. plicatum var. tomentosum 'Summer Snowflake' & $1029.6 \mathrm{a}$ & $518.6 \mathrm{~b}$ & $392.8 \mathrm{~b}$ & $850.6 \mathrm{a}$ & $575.0 \mathrm{~b}$ & - \\
\hline V. pragense 'Decker' & $324.8 \mathrm{a}$ & $312.6 \mathrm{a}$ & $225.8 \mathrm{a}$ & $604.4 \mathrm{a}$ & $465.4 \mathrm{a}$ & $226.4 \mathrm{~b}$ \\
\hline V. $\times$ rhytidophylloides 'Redell' & $598.8 \mathrm{a}$ & $486.2 \mathrm{a}$ & $394.0 \mathrm{a}$ & $1282.0 \mathrm{a}$ & $715.4 \mathrm{~b}$ & $206.4 \mathrm{~b}$ \\
\hline V. trilobum & $649.3 \mathrm{a}$ & $608.6 \mathrm{a}$ & - & $1616.2 \mathrm{a}$ & $438.8 \mathrm{~b}$ & - \\
\hline
\end{tabular}

${ }^{\mathrm{z}}$ Plants were harvested after the fourth irrigation (first harvest, 4 weeks after the initiation of treatment) and eighth irrigation (second harvest, 9 weeks after the initiation of treatment).

${ }^{\mathrm{y}}$ Means with the same lowercase letters within a row and harvest date are not significantly different among treatments by Tukey's honestly significant difference or between treatments by Student's $t$ test at $\alpha=0.05$.

${ }^{\mathrm{x}}$ Data were not collected due to plant death or severe foliar salt damage on survived plant(s).

${ }^{\mathrm{w}} V . \times{ }^{\mathrm{N}} \mathrm{NCVX} 1$ ' plants were harvested only once.

Table 6. Shoot dry weight (DW) of 12 viburnum taxa irrigated with a nutrient solution [electrical conductivity (EC) $=1.3 \mathrm{dS} \cdot \mathrm{m}^{-1}$; control] or a saline solution $\left[\mathrm{EC}=5.0 \mathrm{dS} \cdot \mathrm{m}^{-1}(\mathrm{EC} 5)\right.$ or $\left.10.0 \mathrm{dS} \cdot \mathrm{m}^{-1}(\mathrm{EC} 10)\right]$ in a greenhouse. ${ }^{\mathrm{z}}$

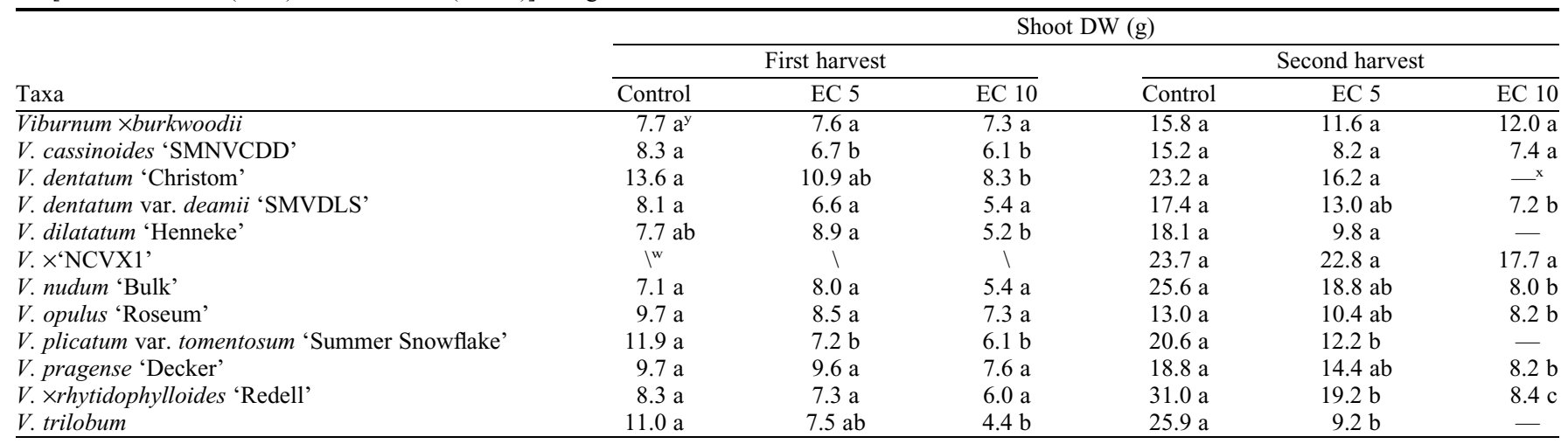

${ }^{\mathrm{z}}$ Plants were harvested after the fourth irrigation (first harvest, 4 weeks after the initiation of treatment) and eighth irrigation (second harvest, 9 weeks after the initiation of treatment).

${ }^{\mathrm{y}}$ Means with the same lowercase letters within a row and harvest date are not significantly different among treatments by Tukey's honestly significant difference or between treatments by Student's $t$ test at $\alpha=0.05$.

${ }^{\mathrm{x}}$ Data were not collected due to plant death.

${ }^{\mathrm{w}} V . \times{ }^{\mathrm{N} C V X} 1$ ' plants were harvested only once. 
Table 7. Relative chlorophyll content [Soil Plant Analysis Development (SPAD)] of 12 viburnum taxa irrigated with a nutrient solution [electrical conductivity $(E C)=1.3 \mathrm{dS} \cdot \mathrm{m}^{-1}$; control] or a saline solution $\left[\mathrm{EC}=5.0 \mathrm{dS} \cdot \mathrm{m}^{-1}(\mathrm{EC} 5)\right.$ or $\left.10.0 \mathrm{dS} \cdot \mathrm{m}^{-1}(\mathrm{EC} 10)\right]$ in a greenhouse. ${ }^{\mathrm{z}}$

\begin{tabular}{|c|c|c|c|c|c|c|}
\hline \multirow{2}{*}{ Taxa } & \multicolumn{6}{|c|}{ SPAD } \\
\hline & \multicolumn{3}{|c|}{ First harvest } & \multicolumn{3}{|c|}{ Second harvest } \\
\hline Viburnum $\times$ burkwoodii & $63.6 \mathrm{a}^{\mathrm{y}}$ & $63.1 \mathrm{a}$ & $68.7 \mathrm{a}$ & $66.4 \mathrm{ab}$ & $61.9 \mathrm{~b}$ & $70.7 \mathrm{a}$ \\
\hline V. dentatum var. deamii 'SMVDLS' & $32.0 \mathrm{a}$ & $28.7 \mathrm{a}$ & $32.0 \mathrm{a}$ & $26.7 \mathrm{a}$ & $25.9 \mathrm{a}$ & $27.9 \mathrm{a}$ \\
\hline V. dilatatum 'Henneke' & $36.5 \mathrm{a}$ & $33.1 \mathrm{a}$ & $42.8 \mathrm{a}$ & $34.6 \mathrm{a}$ & $26.8 \mathrm{a}$ & - \\
\hline$V . \times{ }^{\prime} \mathrm{NCVX} 1$ ' & $42.1 \mathrm{a}$ & $43.4 \mathrm{a}$ & $47.5 \mathrm{a}$ & $51.7 \mathrm{a}$ & $50.5 \mathrm{a}$ & $47.0 \mathrm{a}$ \\
\hline V. plicatum var. tomentosum 'Summer Snowflake' & $44.8 \mathrm{a}$ & $45.7 \mathrm{a}$ & $45.6 \mathrm{a}$ & $42.0 \mathrm{a}$ & $36.2 \mathrm{a}$ & - \\
\hline V. pragense 'Decker' & $60.6 \mathrm{a}$ & $61.0 \mathrm{a}$ & $58.7 \mathrm{a}$ & $59.8 \mathrm{a}$ & $61.4 \mathrm{a}$ & $50.9 \mathrm{~b}$ \\
\hline V. ×rhytidophylloides 'Redell' & $40.5 \mathrm{a}$ & $41.1 \mathrm{a}$ & $43.4 \mathrm{a}$ & $42.0 \mathrm{a}$ & $46.1 \mathrm{a}$ & $18.3 \mathrm{~b}$ \\
\hline V. trilobum & $37.8 \mathrm{a}$ & $33.9 \mathrm{a}$ & $32.8 \mathrm{a}$ & $29.6 \mathrm{a}$ & $23.0 \mathrm{~b}$ & - \\
\hline
\end{tabular}

${ }^{\mathrm{z}}$ Plants were harvested after the fourth irrigation (first harvest, 4 weeks after the initiation of treatment) and eighth irrigation (second harvest, 9 weeks after the initiation of treatment).

${ }^{\mathrm{y}}$ Means with the same lowercase letters within a row and harvest date are not significantly different among treatments by Tukey's honestly significant difference or between treatments by Student's $t$ test at $\alpha=0.05$.

${ }^{\mathrm{x}}$ Data were not collected due to plant death.

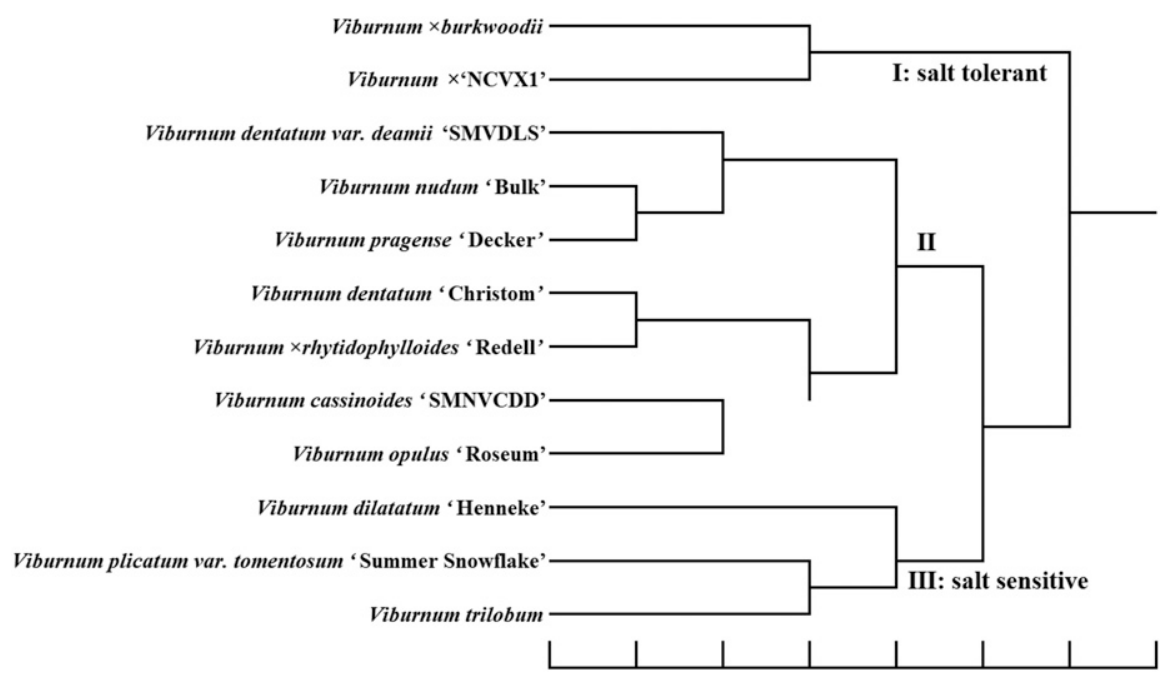

Fig. 4. The cluster analysis of 12 viburnum taxa base on visual score and relative plant height at both harvest dates as well as relative dry weight at the second harvest. The dry weight data at the first harvest was not used because $V$. $\times$ 'NCVX1' plants were harvested only once. Plants were irrigated weekly with saline solution at an electrical conductivity of 5.0 and $10.0 \mathrm{dS} \cdot \mathrm{m}^{-1}$ eight times. Plants were categorized into three groups, with plants in group I the most salt tolerant and plants in group III the most sensitive to saline solution irrigation.

serve as a mechanism for them to tolerate salinity stress.

Cluster analysis. Three major distinguishable groups formed when a cluster analysis was conducted using visual scores and relative plant height of 12 viburnum taxa at both harvest dates as well as relative dry weight at the second harvest (Fig. 4). Viburnum $\times$ burkwoodii and $V . \times$ 'NCVX1' were classified in group I, in which plants were considered the most tolerant to saline solution irrigation. Viburnum dentatum var. deamii 'SMVDLS', $V$. nudum 'Bulk', $V$. pragense 'Decker', $V$. dentatum 'Christom', V. Xrhytidophylloides 'Redell', $V$. cassinoides 'SMNVCDD', $V$. opulus 'Roseum' were grouped in group II with moderate tolerance to saline solution irrigation, while $V$. dilatatum 'Henneke', $V$. plicatum var. tomentosum 'Summer Snowflake', and $V$. trilobum were classified in group III and were sensitive to salinity
(Fig. 4). Viburnum $\times$ burkwoodii and $V$. $\times$ 'NCVX1' displayed better visual quality than other tested viburnum taxa, especially when irrigated with saline solution at an EC of $10.0 \mathrm{dS} \cdot \mathrm{m}^{-1}$ during the study. This indicates that interspecific hybrids may exhibit hybrid vigor that improves abiotic stress tolerance. $V$. $\times$ burkwoodii and $V$. $\times{ }^{\prime} \mathrm{NCVX} 1$ ' are the most tolerant viburnums among all taxa tested in this study. To maintain visual appearance in the landscape where poor quality water such as reclaimed water is used for irrigation, these two viburnum taxa should be considered before others. Viburnum dilatatum 'Henneke', $V$. plicatum var. tomentosum 'Summer Snowflake, and $V$. trilobum were the most sensitive to salinity stress in terms of visual quality. Viburnum dentatum 'Christom', $V$. dentatum var. deamii 'SMVDLS', V. nudum 'Bulk', V. pragense 'Decker', and $V$. ×rhytidophylloides
'Redell' exhibited good visual quality even when irrigated with saline solution at an EC of $5.0 \mathrm{dS} \cdot \mathrm{m}^{-1}$ for 8 weeks and had good visual quality or slight foliar damage at an EC of $10.0 \mathrm{dS} \cdot \mathrm{m}^{-1}$ for 4 weeks. They were relatively more tolerant to the salinity levels in this study than $V$. cassinoides 'SMNVCDD' and $V$. opulus 'Roseum', which had severe to moderate foliar damage when irrigated with saline solution at an EC of $10.0 \mathrm{dS} \cdot \mathrm{m}^{-1}$ for 4 weeks and at an EC of $5.0 \mathrm{dS} \cdot \mathrm{m}^{-1}$ for 8 weeks.

\section{Conclusions}

The degree of salt damage depended on the salinity levels of irrigation solution and the length of exposure to the saline solution. All tested viburnum taxa exhibited various salinity tolerance. $V$. $\times$ burkwoodii and $V$. $\times$ 'NCVX1' were the most salt-tolerant viburnum taxa. When these genotypes were irrigated with saline solution at ECs of 5.0 and $10.0 \mathrm{dS} \cdot \mathrm{m}^{-1}$, they had better visual quality with less growth reductions compared with other viburnum taxa. On the other hand, $V$. dilatatum 'Henneke', V. plicatum var. tomentosum 'Summer Snowflake', and V. trilobum were the least tolerant viburnum taxa to saline solution irrigation with the worst visual quality and the greatest growth reductions. Being widely used ornamental plants, it is important to prevent viburnum plants from salt damage to maintain high-quality specimens in landscape situations. The results from this study may serve as a reference for the green industry to choose relatively tolerant viburnum taxa for landscape use and nursery production where poor-quality water is used for irrigation.

\section{Literature Cited}

Acosta-Motos, J.R., P. Díaz-Vivancos, S. Álvarez, N. Fernández-García, M.J. Sánchez-Blanco, and J.A. Hernández. 2015. NaCl-induced physiological and biochemical adaptative mechanism in the ornamental Myrtus cummunis L. plants. J. Plant Physiol. 183:41-51.

Altland, J.E., J.C. Locke, and C.R. Krause. 2014. Influence of pine bark particle size and $\mathrm{pH}$ on 
cation exchange capacity. HortTechnology 24:554-559.

Álvarez, S. and M.J. Sánchez-Blanco. 2014. Longterm effect of salinity on plant quality, water relations, photosynthetic parameters and ion distribution in Callistemon citrinus. Plant Biol. 16:757-764.

Bañón, S., J. Miralles, E. Conesa, J. Ochoa, J.A. Franco, and M.J. Sánchez-Blanco. 2012a. Effects of salinity and boron excess on the growth, photosynthesis, water relation and mineral composition of laurustinus grown in greenhouse. Acta Hort. 927:379-384.

Bañón, S., J. Miralles, J. Ochoa, and M.J. SánchezBlanco. 2012b. The effect of salinity and high boron on growth, photosynthetic activity and mineral contents of two ornamental shrubs. HortScience 4:188-194.

Beckerman, J. and B.R. Lerner. 2009. Salt damage in landscape plants. Purdue Ext. Bul. ID-412W. West Lafayette, IN. 4 Apr. 2019. <https:// www.extension.purdue.edu/extmedia/ID/ID412-W.pdf>.

Cai, X., Y. Sun, T. Starman, C. Hall, and G. Niu. 2014. Response of 18 Earth-Kind rose cultivars to salt stress. HortScience 49:544-549.

Cassaniti, C., C. Lenardi, and T.J. Flowers. 2009. The effects of sodium chloride on ornamental shrubs. Scientia Hort. 122:586-593.

Cavins, T.J., B.E. Whipker, and W.C. Fonteno. 2008. Pourthru: A method for monitoring nutrition in the greenhouse. Acta Hort. 779:289 297.

Cirillo, C., V.D. Micco, C. Arena, P. Carillo, A. Pannico, S.D. Pascale, and Y. Rouphael. 2019. Biochemical, physiological and anatomical mechanisms of adaptation of Callistemon citrinus and Viburnum lucidum to $\mathrm{NaCl}$ and $\mathrm{CaCl}_{2}$ salinization. Front. Plant Sci. 10:742.

Cirillo, C., Y. Rouphael, R. Caputo, G. Raimondi, M.I. Sifola, and S.D. Pascale. 2016. Effects of high salinity and the exogenous application of an osmolyte on growth, photosynthesis, and mineral composition in two ornamental shrubs. J. Hort. Sci. Biotechnol. 91:14-22.

Farhat, N., M. Rabhi, H. Falleh, K. Lengliz, A. Smaoui, C. Abdelly, M. Lachaâl, and N. Karray-Bouraoui. 2013. Interactive effects of excessive potassium and $\mathrm{Mg}$ deficiency on safflower. Acta Physiol. Plant. 35:2737-2745.

Gavlak, R.G., D.A. Horneck, and R.O. Miller. 1994. Plant, soil, and water reference methods for the western region. Western Regional Ext. Pub. WREP-125. Univ. Alaska, Fairbanks, AK. Gómez-Bellot, M.J., M.F. Ortuño, P.A. Nortes, A. Bernavé, F. Fernández, and M.J. SánchezBlanco. 2018. Effectiveness of bacterial inoculation in alleviation of salinity on water status, mineral content, gas exchange and photosynthetic parameters of Viburnum tinus L. plants. Scientia Hort. 237:303-310.

Gómez-Bellot, M.J., P.A. Nortes, M.F. Ortuño, C. Romero, N. Fernández-García, and M.J. Sánchez-Blanco. 2015. Influence of arbuscular mycorrhizal fungi and treated wastewater on water relations and leaf structure alterations of Viburnum tinus L. plants during both saline and recovery periods. J. Plant Physiol. 188:96-105.

Hanin, M., C. Ebel, M. Ngom, L. Laplaze, and K. Masmoudi. 2016. New ilnsights on plant salt tolerance mechanisms and their potential use for breeding. Front. Plant Sci. 7:1787.

Hewitt, E.J. 1966. Sand and Water Culture Methods Used in the Study of Plant Nutrition, 2nd ed. Commonwealth Agricultural Bureau, London, UK.

Ibrahim, K.M., J.C. Collins, and H.A. Collin. 1990. Effects of salinity on growth and ionic composition of Coleus blumei and Salvia splendens. J. Hort. Sci. 66:215-222.

Laura, G.J. 2009. Winter salt injury and salt tolerant landscape plants. Univ. Wisconsin Coop. Ext. Univ. of Wisconsin-Madison, Madison, WI.

Lippi, G., G. Serra, P. Vernieri, and F. Tognoni. 2003. Response of potted Callistemon species to high salinity. Intl. Symp. on Managing
Greenhouse Crops in Saline Environ. 609:247-250.

Liu, Q., Y. Sun, G. Niu, J. Altland, L. Chen, and L. Jiang. 2017. Morphological and physiological responses of ten ornamental taxa to saline water irrigation. HortScience 52:1816-1822.

Munns, R. and M. Tester. 2008. Mechanisms of salinity tolerance. Annu. Rev. Plant Biol. 59:651-681.

Rabhi, M., N. Farhat, N. Msilini, H. Rajhi, A. Smaoui, C. Abdelly, M. Lachaâl, and N. Karray-Bouraoui. 2018. Physiological responses of Carthamus tinctorius to $\mathrm{CaCl}_{2}$ salinity under $\mathrm{Mg}$-sufficient and $\mathrm{Mg}$-deficient conditions. Flora 246-247:96-101.

Shah, H.S., R. Houborg, and M.F. McCabe. 2017. Response of chlorophyll, carotenoid and SPAD-502 measurement to salinity and nutrient stress in wheat (Triticum aestivum L.) Agron. 7:61.

Sifola, M.I., C. Cirillo, Y. Rouphael, R. Caputo, A. Pannico, G. Raimondi, E.D. Stasio, and S.D. Pascale. 2017. Effect of water salinity and osmolytes application on growth and ornamental value of Viburnum lucidum L. Acta Hort. 1170:659-664.

Sun, Y., G. Niu, and C. Perez. 2015. Relative salt tolerance of seven Texas Superstar ${ }^{\circledR}$ perennials. HortScience 50:1562-1566.

Taiz, L., E. Zeiger, I.M. Møller, and A. Murphy. 2015. Plant physiology and development. 6th ed. Sinauer Associates, Sunderland, MA.

Wu, S., Y. Sun, G. Niu, J. Altland, and R.I. Cabrera. 2016. Response of ten aster species to saline water irrigation. HortScience 51:197-201.

Yeager, T.H., J.K. von Merveldt, and C.A. Larsen. 2010. Ornamental plant response to percentage of reclaimed water irrigation. HortScience 45:1610-1615.

Zimmerman, E.M., L.G. Jull, and A.M. Shirazi. 2005. Effects of salinity and freezing on Acer platanoides, Tilia cordata, and Viburnum lantana. J. Environ. Hort. 23:138-144. 